\title{
The Study of the Effects of Yunnan Yuxi Dialect on Received Pronunciation
}

\author{
Yuanfei Yao \\ West China Normal University, Nanchong, Sichuan 637000, China
}

\begin{abstract}
Abstact-In A Brief Analysis of Yuxi Dialect, Fu Chang makes a detailed explanation on dialects' features and the value of its study. In The General Received Pronunciation of British English by Fengtong Chang, the author dealt with reasons why London English became standard English, and also elaborated on consonants and vowels in British English. Up to today no one has ever made a contrast between the two languages and further diminished the interference from dialect in English pronunciation learning of the Yuxi students. This paper is designed to make a contrast between the two languages: Yuxi dialect in Zhoucheng and Received Pronunciation; as well as the differences between their consonants and vowels respectively can be achieved to rectify the pronunciations' deviation in English learning. It is intended to improve English teaching quality of Yuxi dialect speakers and enhance the pronunciation standardization of English there.
\end{abstract}

Index Terms-Yuxi dialect, RP, vowels and consonants, differences, rectifications

\section{INTRODUCTION}

There are a variety of dialects in the world. Dialects influence language how learners approach a target language. This rule applies to students in Yuxi, too. But So far no one has ever made a contrast between the two languages and further diminished the interference from English dialect's pronunciation learning in any data.

As a Yuxi local, the writer, having an experience of learning English there for years, finds that the local dialect has a negative impact on his pronunciation of English. However, there is no such solution to this problem until now. Therefore, this paper, having based itself on A Brief Analysis of Yuxi Dialect by Fu Chang, analyzes consonants and vowels in the Yuxi dialect. Then it cites the reasons given in The General Received Pronunciation of British English by Fengtong Chang on why British English was chosen as the standard English.

Next, it analyzes consonants and vowels in British English and then makes a comparison between consonants and vowels in the two languages.

Finally, it states the difference between the two languages in terms of consonant and vowel and accordingly reaches a conclusion: consonants in the Yuxi dialect will have negative impacts on the pronunciation of English words if they sound similar to the equivalent English consonants.

\section{AN INTRODUCTION OF YUNNAN YUXI DiaLECT}

Yuxi dialect stands out among the other dialects of Yunnan. It is mainly spoken in Zhoucheng of Yuxi, including Yuxi plain and Yanhe plain and villages in the semi-hills surrounding the city, wherein the Han Chinese live. Among all the villages, only Daying Street in the north of the city is inhabited by the Hui ethnic group. Hui dialect has its own phonetic system, i.e., they speak with no gutturophony but velar. Furthermore, the phonetic system, which is similar to that of the Kunming dialect, does not belong to Yuxi dialect. In terms of vocabulary and sound system, the dialect of Yanhe is sharply different from that of Zhoucheng, whereas the phonetic system of the former is the same as that of the latter, which uses initial consonant of back guttural, hence the former can be classified into the Yuxi dialect.

Fu Chang, a Chinese linguist, conducted a survey on Yuxi dialect. Once he heard some people talking and coughing when they were bargaining. He noticed that he could not understand what they were talking about. So, he made an effort to listen to them and finally figured out that they were speaking with a local dialect called Ximuhongyin (Ximu, an old initial consonant: hongyin, kaikouhu.) Ximuhongyin features initial consonants whose pronunciations are similar to coughing, which is a rare phenomenon. Dialects in Yunnan by Luo changpei names four representative regions: Kunming, Dali, Yuxi, Qiaojia. All of these reasons prove that Yuxi dialect is in a special position in the field of language studying. Out of the concern of unity, this paper bases the analysis and discussion of the Yuxi dialect on the dialect spoken in the Zhoucheng area.

This peculiarity can find its full expression in that the glottal stops [?][?h] and the guttural fricative $[\mathrm{h}]$ correspond to the lingual plosive $[\mathrm{k}]\left[\mathrm{k}^{\mathrm{h}}\right]$ and the lingual fricative $[\mathrm{x}]$ in standard Chinese. This phenomenon is so rare that it once aroused the interest of many experts both at home and abroad.

The characteristics of the Yuxi dialect lie in that, besides the three guttural initials [?][?h][h], it also has another two initial consonants of voiced dental fricatives: [v][z]. Chinese characters in the Yuxi dialect like “闻文吻问微望万尾” are uttered with $[\mathrm{v}]$ as their initial consonant. However, initial consonant $[\mathrm{z}]$ is only heard in such Chinese characters in 
Yuxi dialect “宇游” that have their own syllables and dialect corresponds to syllables of zero-consonant in mandarin, such as “因营莹颖㚣缨盈英影映樱莺应匀韵允殷隐印”, etc.. As for simple or compound vowels of Chinese syllable, Qichihu (齐齿呼) compound vowels appear in Yuxi dialect but this is not true with Cuokouhu（撮口呼）because all Chinese characters with Cuokouhu combine into their relative Qichihu. Similar to the Kunming dialect, [ĩ] and [ẽn] rise and [ii] and [ə]] fall. Additionally, the striking characteristic of the Yuxi dialect is that [uən], [uang], [uan ] are uttered as the same [uẫn], and Chinese characters like “温汪弯光关” are uttered identically. The rhyme Chinese characters(韵 字) consist of the majority of those with vowels of ə, uo, o and part of those with [ao], [ei], [ai], which is of much distinction. In respect of the combination law of the initial consonants and the simple or compound vowels, the vowel [ĩn] can collaborate with the four consonants [ts], [t $\left.\mathrm{s}^{\mathrm{h}}\right],[\mathrm{s}],[\mathrm{z}]$, but not with [tc], [t6 $]$, which is a far cry from standard Chinese or Kunming dialect.

Over the past forty years, due to the rapid development of politics, economy, culture and education, the dialect in Yuxi city has changed drastically. There, locals under the age of thirty have begun to speak a new Yuxi dialect that is much more similar to the Kunming dialect. The prominent feature of the new the Yuxi dialect is gutturophony. That is to say, the initial consonant has been replaced by velar, and the vowel [ə] has diverged from [o], and [in] has begun to detach themselves from[ts], $\left[\mathrm{ts}^{\mathrm{h}}\right],[\mathrm{s}]$, and collaborated with [tc] and [z]. Moreover, the initial consonants are disappearing gradually. The outstanding characteristics of the traditional the Yuxi dialect have almost faded away, indicating that it is becoming more similar to standard Chinese. However, the old Yuxu dialect spoken by indigenous people in Zhoucheng and its surrounding countryside has maintained its own features.

\section{The CONSONANTS AND Vowels OF THE YuXI Dialect}

\section{A. The Consonants of the Yuxi Dialect (the Initial Consonants of Chinese Syllables)}

In Yuxi dialect, there are 24 (include: zero-consonant(零声母)) consonants displayed in the following table:

\begin{tabular}{|c|c|c|c|c|c|}
\hline & \multicolumn{5}{|c|}{$\begin{array}{c}\text { TABLE } 1 \\
\text { (Fu CHANG, 1991(4), P.33.) }\end{array}$} \\
\hline p & 布北 & $p^{4}$ & 怕䆝 & $\mathrm{m}$ & 门感 \\
\hline f & 飞凂 & $\mathbf{v}$ & 文厅 & & \\
\hline t & 道夺 & $t^{6}$ & 太闰 & $\mathrm{n}$ & 㣮怒 \\
\hline 1 & 兰路 & & & & \\
\hline$?$ & 贵街 & $P^{6}$ & 死葵 & $\mathrm{h}$ & 化鞋 \\
\hline to & 节家 & toc & 区恰 & 6 & 小休 \\
\hline ts & 招主 & tss" & 昌虫 & $\mathbf{s}$ & 声扮 \\
\hline$z$ & 日然 & & & & \\
\hline ts & 资金 & ts & 雌清 & s & 私心 \\
\hline$z$ & 营云 & $\emptyset$ & 安衣 & & \\
\hline
\end{tabular}

Attention to the following rules:

First, pronunciations of such consonants as $[\mathrm{p}]\left[\mathrm{p}^{\mathrm{h}}\right][\mathrm{m}][\mathrm{f}][\mathrm{t}]\left[\mathrm{t}^{\mathrm{h}}\right][\mathrm{n}][\mathrm{l}][\mathrm{t}]\left[\mathrm{tc}^{\mathrm{h}}\right][\mathrm{c}][\mathrm{ts}]\left[\mathrm{t}^{\mathrm{h}}\right][\mathrm{s}]$ are the same as that of Mandarin.

Second, the retro-flex degree of the four consonants [ts] [ts $][s][z]$ is not as high as Mandarin, to the degree of palatal alveolar [tg $\left[\mathrm{tg}^{\mathrm{h}}\right][\mathrm{f}][\mathrm{3}]$.

Third, the two consonants [v] and [z] are not included in Mandarin; [v] is a labial-dental fricative, [z] is a tip-tongue fricative.

Fourth, present pronunciation of the guttural fricative $[\mathrm{h}]$ is close to that of the lingual fricative $[\mathrm{x}]$, but in light of the integrity of the Yuxi phonetic system and its tradition, the former is still marked as ${ }^{\mathrm{h}}$.

B. The Vowels of the Yuxi Dialect (the Simple and Compound Vowels)

There are 31 vowels in the Yuxi dialect: 
TABLE 2

(Fu CHANG, 1991(4), P.34.)

\begin{tabular}{|c|c|c|c|c|c|}
\hline 1 & 资磁 & $\imath$ & 知吃 & A & 㹝巴 \\
\hline o & 波多鹅溥北黑拍 & & & $\partial$ & 他㖃 \\
\hline $\boldsymbol{r}$ & 儿尔 & $\mathrm{Ae}$ & 艾矮 & E I & 杯佩 \\
\hline as & 刀了猔 & $s u$ & 伙㳔 & & \\
\hline i & 衣鱼 & iA & 家呀 & io & 药学 \\
\hline io & 雀鹊 & $\mathrm{i} \varepsilon$ & 耶月 & iu & 育局 \\
\hline ias & 腰交 & $\mathbf{i} \partial \mathbf{u}$ & 油修 & & \\
\hline $\mathbf{u}$ & 乌木 & $\mathbf{u A}$ & 瓜花 & uAe & 歪怪 \\
\hline UEI & 威旃 & & & & \\
\hline$\tilde{\mathbf{A}} \mathbf{n}$ & 安干 & $\tilde{\mathrm{A}} \mathfrak{y}$ & 吊掌 & ãn & 根生 \\
\hline on & 东朋翁 & $i \tilde{E} n$ & 烟元 & iÃn & \\
\hline$\tilde{1} n$ & 因英云 & ion & 永容 & ũ̃n & 昷汪 \\
\hline
\end{tabular}

Attention to the following rules:

First, lips should be extended wider than of the two mono-vowels $[\mathrm{u}]$ and $[\mathrm{o}]$ be wider than that of them in standard Chinese.

Second, the retro-flex degree of the mono-vowel [o] is not as high as that of its correspondent in standard Chinese.

Third, only a few Chinese characters have the mono-vowel [ə], such as“他,呢”, while many Chinese characters contain mono-vowel [o], such as $\gamma$, uo, o and some characters of ao, ei in Chinese vowels.

Fourth, there are no Cuokouhu vowels in Yuxi dialect; most Cuokouhu vowels in Chinese have merged into Qichihu vowels and only a few Cuokouhu vowels have merged into Hekouhu vowels.

Fifth, the openness of the vowel [Ae] is bigger than that of its correspondent in Mandarin.

Sixth, nasal tail vowels are peculiar to Yuxi dialect, they include main vowels [on] [ ion].

\section{An InTRoduction of ReCEIVEd PRONunCiation AND Vowels AND CONSONANTS OF RP}

\section{A. The Reasons of RP as the Standard English}

British English (BriE.) mainly refers to the laws of English by the English people living on the British Isles. It is the official language of the UK and the Commonwealth. British English symbolizes the nobility and elegance of the English and with its clear pronunciation; it is very popular among many English learners. However, not all the British embrace British English. In some parts of the UK, especially Scotland, Wales and Northern Ireland, people there advocate the coexistence of diverse dialects, sharing the idea that to require all the people to speak the same language amounts to a kind of unreasonable insult. On the part of the people in England, the evolution of dialects is an extremely serious problem.

In history, the powerful British Empire dominated world culture. The most influential British English (RP, Received Pronunciation) usually refers to the non-dialect English spoken by the educated living in the main college cities of England, such as Oxford University and Cambridge University. Moreover, this kind of English is also used in boarding schools and on television and radio broadcast and is labeled as "English accent". That being said, many countries are still reluctant to acknowledge this type of English, the US, for instance.

Currently British English is still the official language of many Commonwealth countries, such as: Australia, South Africa and India. This is also true of the European Union. In China, British English is spoken in Britain's former colony, Hong Kong. The broadcasters of the BBC employ British English in the London area as well, while many English learners in China practice listening with the BBC. Therefore, this paper takes Received Pronunciation as the Standard English.

\section{B. The Consonants and Vowels in RP}

\section{The Consonants in RP}

There are 24 distinctive phonemes in the English consonant system in RP. According to the manner of articulation, they can be classified as follows: 


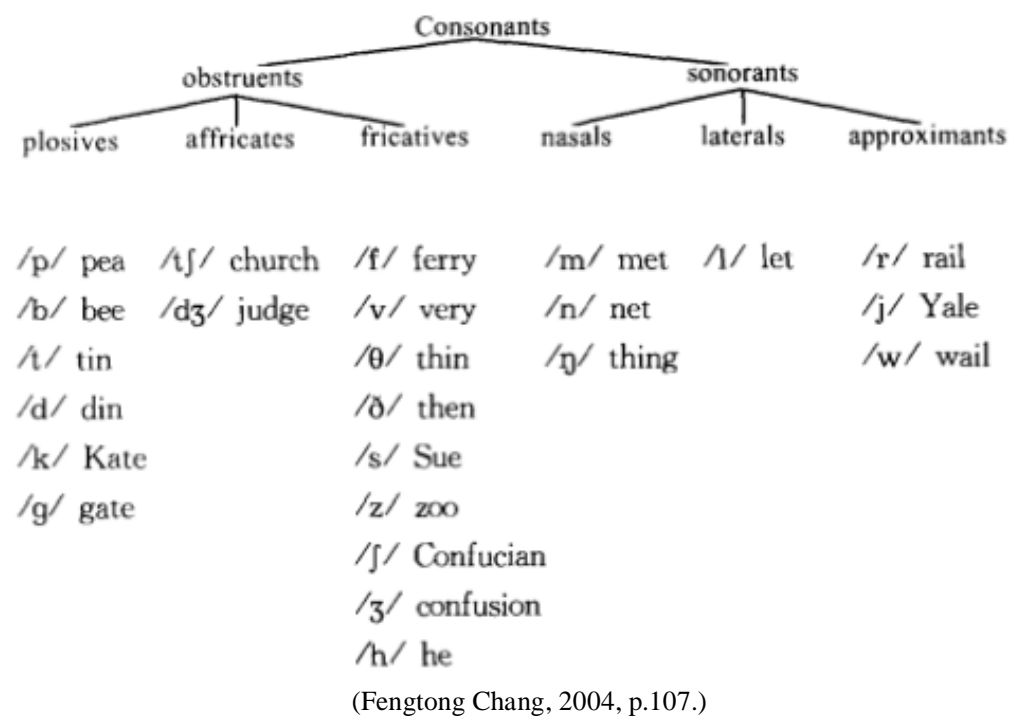

English consonant can also be classified according to the place of the articulation as follows:

1) 3 bilabials: $[\mathrm{p}][\mathrm{b}][\mathrm{m}]$ as in pet, bet, met

2) 2 labio-dentals: [f] [v] as in fan, van

3) 2 dentals: $[\theta][ð]$ as in breath, breathe

4) 6 alveolars: [t] [d] [s] [z] [n] [1] as in teen, dean, seal, zeal, no, low.

5) 1 post-alveolar: [r] as in red

6) 4 palate-alveolars: [t] [d] [J] [3] as in cheep, jeep, mention, measure.

7) 1 palatal: [j] as in you.

8) 4 velars: [g] [k] [y] [w] as in kill, gill, sing, wing

9) 1 glottal: [h] as in here

In addition, English sounds can also be classified according to the feature of voicing as follows:

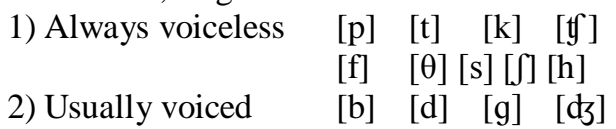

2) Usually voiced $\quad[\mathrm{b}] \quad[\mathrm{d}] \underset{[\mathrm{v}][\mathrm{g}]}{[\mathrm{d}]}[\mathrm{d}][3]$
$[\mathrm{z}]$

$[\mathrm{m}][\mathrm{n}][\mathrm{y}]$

$[1] \quad[r] \quad[j] \quad[w]$

3) Always voiced vowels and diphthongs

(Fengtong Chang, 2004, p.107)

All are referred to loosely as " voiced sounds "

\section{The Vowels in RP}

These sounds may be classified according to the following principles:

a. Monophthongs (relatively pure vowels): in producing these vowels the position and shape of the tongue and the shape of the lips stay more or less unchanged.

1) The part of the tongue raised

(1) 4 front: [i:] [I] [e] [æ] as in beat, bit, bet, bat

(2) 3 central: [^] [3:] [ə] as in luck, lurk, alert

(3) 5 back: [a:] [v] [o:] [v] [u:] as in fast, fog, fork, foot, food

2) The shape of the lip

(1) 4 rounded: [p] [o:] [v] [u:] as in fog, fort, foot, food

(2) 8 unrounded: [i:] [r] [e] [æ] [^] [a:] [3:] [ə] as in piece, pig, peg, pad, pub, park, purse, purpose

3) The openness of the mouth:

(1) close : [i:] [r] [v] [u:]

(2) semi close: $[\mathrm{e}][\mathrm{o}]$

(3) semi open: $[\wedge][\varepsilon:]$

4) length:

(4) open: [æ] [a] [p] [a:]

(1) tense (long vowels): [I] [ช] [e] [ə] [æ] [^] [p]

(2) lax (short vowels): [i:] [a:] [3:][u:][0:]

b. Diphthongs: in their production there is a glide within one syllable from one vowel position to another and the first element is longer, stronger and more sonorant than the second. 


\section{1) 5 closing diphthongs}

(1) gliding to [I]: [еІ] [aI] [эI] as in bay, buy, boy

(2) gliding to $[\mho]:[\partial \mho][\mathrm{a}]]$ as in bode, bowed

2) 3 centering diphthongs gliding to [ə]: [Іә] [еə] [0॰] as in peer, pear, poor

(Fengtong Chang, 2004: 61)

\section{A COMPARISON BETWEEN THE YUXI DiALECT AND RP}

\section{A. The Differences Between Consonants of the Yuxi Dialect and That of RP}

After comparing table 1 with table 2, the writer finds that there are 24 consonants in the alphabet of RP and 24 consonants in the Yuxi dialect. These two languages are different in the number of their consonants. Meanwhile, Yuxi

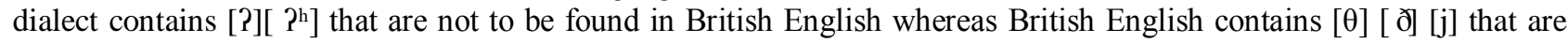
also not to be found in the Yuxi dialect. Zero consonant in the two languages, however, is not to be dealt with.

Yuxi dialect has twenty-four consonants, including zero-consonant(零声母) (which this essay will not cope with), while British English has twenty-four consonants. Since zero-consonant(零声母) will not be used in the comparison of the two tongues, British English therefore has two more consonants than the Yuxi dialect.

The description of Yuxi dialect consonants:

TABLE 3

\begin{tabular}{|c|c|c|c|c|c|c|c|c|c|}
\hline \multirow{2}{*}{ position } & \multicolumn{2}{|c|}{ plosive } & \multicolumn{2}{|c|}{ Glottal stop } & \multicolumn{2}{|c|}{ fricative } & \multirow{2}{*}{$\begin{array}{l}\text { Nasal } \\
\text { sound }\end{array}$} & \multirow{2}{*}{$\begin{array}{l}\text { Lateral } \\
\text { sound }\end{array}$} & \multirow{2}{*}{ Zero-consonant } \\
\hline & $\begin{array}{c}\text { Unaspirated } \\
\text { sound }\end{array}$ & $\begin{array}{c}\text { Aspirated } \\
\text { sound }\end{array}$ & $\begin{array}{c}\text { Unaspirated } \\
\text { sound }\end{array}$ & $\begin{array}{c}\text { Aspirated } \\
\text { sound }\end{array}$ & $\begin{array}{c}\text { voiceless } \\
\text { sound }\end{array}$ & $\begin{array}{l}\text { Voiced } \\
\text { sound }\end{array}$ & & & \\
\hline bilabial & $\mathbf{p}$ & $\mathbf{p}^{\mathrm{h}}$ & & & & & m & & \\
\hline dentilabial & & & & & f & $\mathbf{v}$ & & & \\
\hline supradental & & & ts & $\mathbf{t s}^{\mathrm{h}}$ & $s$ & $\mathbf{Z}$ & & & \\
\hline $\begin{array}{l}\text { blade-alveo } \\
\text { lar }\end{array}$ & $\mathbf{t}$ & $t^{\mathrm{h}}$ & & & & & $\mathbf{n}$ & $\mathrm{L}$ & $\varnothing$ \\
\hline $\begin{array}{l}\text { blade-palat } \\
\text { al }\end{array}$ & & & ts & $\mathbf{t s}^{\mathrm{h}}$ & s & $\mathbf{z}$ & & & \\
\hline dental & & & tc & $t c^{\mathrm{h}}$ & c & & & & \\
\hline glottal & $?$ & $2^{\text {h }}$ & & & h & & & & \\
\hline
\end{tabular}

(Fu Chang, 1991(4), p. 33.)

The description of RP consonants:

TABLE 4

\begin{tabular}{|c|c|c|c|c|c|c|c|c|}
\hline & & Bilabial & Labio-dental & Dental & Alveolar & Palatal & Velar & Glottal \\
\hline \multirow[t]{2}{*}{ Stops } & VL & $\mathrm{p}$ & & & $\mathrm{t}$ & & $\mathrm{k}$ & \\
\hline & VD & $\mathrm{b}$ & & & $\mathrm{d}$ & & $\mathrm{g}$ & \\
\hline \multirow[t]{2}{*}{ Fricatives } & VL & & $\mathrm{f}$ & $\theta$ & s & $\int$ & & $\mathrm{h}$ \\
\hline & VD & & $\mathrm{v}$ & ð & $\mathrm{z}$ & 3 & & \\
\hline \multirow[t]{2}{*}{ Affricates } & VL & & & & $(t)$ & $t$ & & \\
\hline & VD & & & & (b) & ds & & \\
\hline Nasals & VD & $\mathrm{m}$ & & & $\mathrm{n}$ & & $\eta$ & \\
\hline Liquids & VD & & & & $1, \mathrm{r}$ & & & \\
\hline Glides & VD & $\mathrm{w}$ & & & & j & & \\
\hline
\end{tabular}

(Weidong Tai, 013. P.17.)

\section{B. The Effects of the Differences of Consonants Between Yuxi Dialect and RP}

Yuxi dialect, compared with RP, has unique guttural fricatives. However, the Yuxi dialect lacks $[\mathrm{k}]$ and $\left[\mathrm{k}^{\mathrm{h}}\right]$ in British English. This occasion is very likely to affect pronunciations of $[\mathrm{k}]$ and $\left[\mathrm{k}^{\mathrm{h}}\right]$. Therefore, when pronouncing letters $\mathrm{k}$ and $\mathrm{g}$, learners need to make a special effort to alleviate the adverse effects guttural fricatives of the Yuxi dialect has on their pronunciations, for instance: glass[gla:s] in English tends to be pronounced as [?la:s] by students speaking the Yuxi 
dialect; $\operatorname{color}\left[\mathrm{k}^{\mathrm{h}} \mathrm{l}(\mathrm{r})\right]$ could be pronounced as [?hlə(r)], etc..

In addition, nasal consonants [m] [y], due to their tongue position, also have negative impacts on the pronunciation of British English. Nasal vowels and Complex nose ends, under the influence of the Yuxi dialect, will be pronounced as [n]. For example: students speaking the Yuxi dialect may pronounce swim [swim] and swimming [swimin] as [swin] and [swimin].

Some phonetic symbols like [ $\theta][ð]$ are absent in the dialect, but there are similar sounds: [s][z]. Students, therefore, tend to pronounce $[\theta][ð]$ as $[\mathrm{s}][\mathrm{z}]$. Pronouncing $[\theta][\delta]$ requires tongue-biting, whereas students of Yuxi dialect usually do not and this causes non-standard pronunciations. For example thank (correct pronunciation: $\left[\theta æ \eta \mathrm{k}^{\mathrm{h}}\right]$ ) for example, it is mispronounced as [sæyk $\left.\mathrm{k}^{\mathrm{h}}\right]$; the [ð ə] (with [ð]) is mispronounced as [zə].

Finally, as the Yuxi dialect contains $\left[\mathrm{tch}^{\mathrm{h}}\right]\left[\mathrm{s}^{\mathrm{h}}\right][\mathrm{ts}]$ whose equivalents cannot be found in British English, students speaking this dialect are unlikely to mispronounce these consonants. Therefore this paper will not address.

\section{The Differences Between Vowels of Yuxi Dialect and That of RP}

There is little difference between the Yuxi dialect and RP. This paper mainly focuses on the comparison of the vowels that are absent in the two languages. Nevertheless, some vowels are similar in terms of pronunciation, such as: nasal vowels and complex nose ends. The differences of cavity and resonant structure between the people of Europe, the U.S and the East also have an influence on the listeners. It can be found through comparison that a slight difference of pronunciation position does occur in vowels of Yuxi dialect, that is, the vowels of the Yuxi dialect are in the near front, while that of English are in the near back of the tongue. In addition, this pronunciation closely relates to the involvement of expiration and resonance.

Vowels in the Yuxi dialect are mainly monophthongs, compound vowels, nasal vowels and compound nasal vowels, while vowels in RP consist of monophthongs and diphthongs.

The description of vowels of the Yuxi Dialect:

TABLE 5

\begin{tabular}{|c|c|c|c|c|c|c|c|c|c|c|c|c|c|c|}
\hline lips shape & \multicolumn{10}{|c|}{ Vowels and Compound vowel finals } & \multicolumn{4}{|c|}{$\begin{array}{l}\text { Nasal vowels and Complex nose } \\
\text { end finals }\end{array}$} \\
\hline KaiKouHu & 1 & 2 & $\mathrm{~A}$ & $\mathrm{o}$ & $\partial$ & $\partial$ & $\mathrm{Ae}$ & EI & as & әu & An & ən & $\mathrm{An}$ & on \\
\hline QiChiHu & $\mathrm{i}$ & is & iA & io & i $\varepsilon$ & $\mathrm{iu}$ & & & ias & iəu & isn & ĩn & iAn & ion \\
\hline HeKouHu & $\mathrm{u}$ & & $\mathrm{uA}$ & & & & uAe & UEI & & & uAn & & & \\
\hline
\end{tabular}

(Fu Chang, 1991(4), p.34.)

The descriptions of vowels of RP:

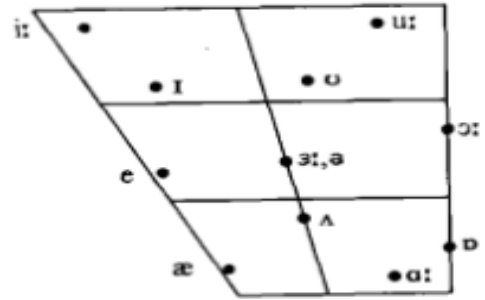

Fig. 2.1 General RP pure vowels

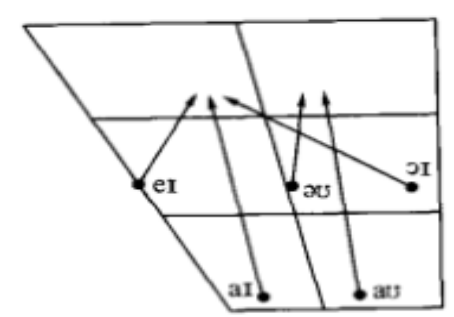

Fig. 2.2 General RP closing diphthongs

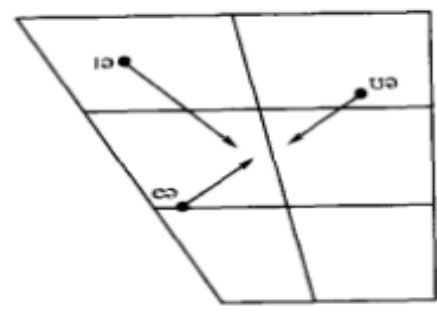

Fig. 2.3 General RP centring diphthongs (Fengtong Chang, 2004, p.57.)

Diphthongs:

5 closing diphthongs

(1) gliding to [I]: [eI] [aI] [oI]

(2) gliding to $[\mho]:[\partial \mho][a v]$

3 centering diphthongs gliding to [ə]:[Іә] [eə] [ひə]

In the Yuxi dialect the vowels do not differentiate in length; the nasalized vowels aside, learners study English vowels 
following the rules of pronunciation of English vowel.

So this will not influence English vowel pronunciation. Therefore, vowels are beyond the description in this paper.

\section{RECTIFICATIONS OF MisPRONUNCIATIONS INFLUENCED By DiALECT}

\section{A. Ways of Rectifying English Consonants' Mispronunciations Influenced by Dialect}

According to the differences between consonants of the Yuxi dialect and that of British English, learners can contrast their pronouncing systems so that one can correct the mispronunciations. [ $\left.{ }^{\mathrm{h}}\right],[?],[\mathrm{m}],[\mathrm{n}],[\mathrm{g}]$ and $[\theta],[\delta]$ would interfere with the pronunciation of British English. 4.3 has shown the concrete inferences.

Correct $\left[?^{\mathrm{h}}\right],[?]$. When learners pronounce $\left[\mathrm{k}^{\mathrm{h}}\right][\mathrm{k}]$, which are blasting consonants in the back tongue soft palate, learners should bulge at the back of the tongue near the soft palate, holding breath, and then immediately divide, letting airflow come out of the mouth to form plosive. [ $\left[\mathrm{k}^{\mathrm{h}}\right]$ is a voiceless consonant without vocal cords vibration; while $[\mathrm{k}]$ is a voiced consonant with vocal cords vibrate.

When learners pronounce nasal consonants, they need to pay attention to the following points: First, letter $\mathrm{m}$ is a Double Lip Nasal Consonant. When learners pronounce it, they should close our lips to allow airflow to come out from the nasal cavity. Second, letter $n$ is Apico-alveolar nasal consonant. When learners pronounce it, their tongues should rise up against the gums to allow airflow to come out from the nasal cavity. Third, sound ng is a back tongue soft-palate nasal consonant. When learners pronounce it, they should block their oral cavity to allow vocal cords to vibrate so that air flow can come out from the nasal cavity.

In addition, because some consonants in the Yuxi dialect are similar to that of British English, such as $\left[\mathrm{p}^{\mathrm{h}}\right][\mathrm{p}]\left[\mathrm{t}^{\mathrm{h}}\right][\mathrm{t}]$ [f] [v], when pronouncing them, learners need to be particularly careful to avoid the slightest errors.

Below are detailed explanations of pronunciations of some representative consonants.

$[\mathrm{p}]$ is a lips blasting consonant. When learners pronounce it, they should close their lips to hold breath, and then open them to let air rush out of the mouth to form plosive.

$\left[\mathrm{t}^{\mathrm{h}}\right]$ is the pronunciation of letter $\mathrm{t}$; while [t] is the pronunciation of letter $\mathrm{d}$. When learners pronounce it, the tips of tongue should reach the upper alveolar ridges. Next they should hold their breath and then separate their lips immediately to let airflow come out of the mouth to form a plosive. [ $\left.\mathrm{t}^{\mathrm{h}}\right]$ is a voiceless consonant; while [t], a voiced consonant.

$[\mathrm{w}]$ is the pronunciation of letter $\mathrm{w}$ called back-tongue soft palate semivowel. When learners pronounce it, they should lift the back of their tongues, close their lips and pout forward, then immediately slide their lips back to two sides to produce a short pronunciation with vocal cord vibration.

[j] is the pronunciation of Chinese letter $y$ in the initial of the word called front tongue hard palate semivowel. When learners pronounce it, the front of the tongue should be lifted to the hard palate as far as possible with a higher position, with lips stretched into flat shape. This semivowel in Chinese pronunciation is actually a voiced consonant with vocal cord vibration.

[1] is the pronunciation of letter 1 called tongue-side and gum-edged consonants. When pronounced, the tongue tip should close to the gum tightly with the tongue lifted up to the hard palate, letting airflow come out from the mouth beside the tongue; When learners pronounce this note as an end syllable, the tongue tip lifted against the upper gum, the front tongue rose, back tongue sank, forming a concave shape. It is a voiced consonant with vocal cord vibration.

[f] is the pronunciation of letter $\mathrm{f}$ and $\mathrm{ph}$ while [v], the pronunciation of letter $\mathrm{v}$ called Affricative consonant. When learners pronounce, the lower lip touched the upper teeth slightly with airflow passed through teeth, forming a fricative. [f] is a voiceless consonant without vocal cords vibration; while [v] is a voiced consonant with vocal cord vibration.

$[\theta]$ and [ð] are the pronunciation of letter th called Tongue-tooth fricative. When learners pronounce, the tip of the tongue touched the upper back of gum, letting airflow come out between the teeth and the tongue to form rubs. [ $\theta$ ] is a voiceless consonant without vocal cords vibration; while[ð], a voiced consonant with vocal cord vibration.

$[\mathrm{s}]$ and $[\mathrm{z}]$ are the pronunciation of letter $\mathrm{s}$ and $\mathrm{z}$, the pronunciation of letter $\mathrm{z}$ at the same time called Tongue-tooth fricative. When learners pronounce them, the tongue side should close near the gum, with airflow coming out between the tongue side and the gum, forming a fricative. [s] is a voiceless consonant without vocal cords vibration; while [z] is a voiced consonant with vocal cord vibration.

[]$]$ is the pronunciation of letter sh while [3], the pronunciation of letter s. They are called back tongue-gum fricatives. When learners pronounce, the tongue side closed near the back of the gum, the tongue lifted near the upper jam, with rounded and slightly exerted lips to form fricative with airflow gets through. [j] is a voiceless consonant without vocal cords vibration; While [3], a voiced consonant with vocal cord vibration.

$[\mathrm{h}]$ is the pronunciation of letter $\mathrm{h}$ that is called glottis fricative. When learners pronounce, the airflow comes out of the mouth with a slight friction with the glottis while the mouth shape changed in accordance with the subsequent vowel. $[\mathrm{h}]$ is a voiceless consonant without vocal cords vibrations.

[z] is the pronunciation of letter $r$ called back tongue-gum fricatives. When learners pronounce, the tip of the tongue curled close to the upper gum on the back, the shape of tongue rounded in slightly, and lips exerted slightly to make airflow form slight friction when getting through the tip of the tongue and the gum. It is a voiced consonant with vocal cord vibration.

[t] is the pronunciation of letter ch while [d]], the pronunciation of letter dge called Tongue end-gum affricates. 
When learners pronounce, the tongue body lifted with the tongue end touched the gum on the back forming a hinder, with which broken through by the airflow. After the airflow come out, the slit between tongue and the gum remained to form affricative when airflow getting through. [t] is a voiceless consonant without vocal cords vibration; while [d] is a voiced consonant with vocal cord vibration.

[ts] and [z] are traditional pronunciation symbols in IPA. However, they are included neither in American nor British pronunciation new textbooks. Affricates [ts] [ct are the pronunciation of the letter combination letter ts and ds respectively called Tongue end-gum affricates. When learners pronounce, the Tongue end stuck on the upper gum first to plug the airflow, then fell down slightly to send airflow out of the mouth. [ts] is a voiceless consonant, while [cz] a voiced consonant.

The two consonants in dialect $\left[\mathrm{tg}^{\mathrm{h}}\right]\left[\mathrm{ts}^{\mathrm{h}}\right][\mathrm{ts}]$ have no counterparts or similar consonants in British English, so there are no effects on the application of those consonants. Therefore, it is not required to do corrections.

\section{B. The Rectification of Vowels Affecting English Pronunciation}

Through the comparison of the position and height of the tongue, the shape of the lips, the openness of the mouth and the length of the vowels based on the vowels' pronunciations, differences between the two languages can be achieved. In Yuxi dialect the vowels do not differentiate in length; the nasalized vowels rectified aside, learners study English vowels following the rules of English vowel' pronunciation. Nasalized vowels are influenced by [n], hence pronunciation deviations can be solved by the rectification methods offered in 6.1 .

\section{CONCLUSION}

Assisted by the brief analysis of the Yuxi dialect by Fu Chang and the writer's experience of learning English, this paper briefly analyzes consonants and vowels in the Yuxi dialect. When reading The General Received Pronunciation of British English by Fengtong Chang, the writer found that Chang gives a full explanation on the reasons why British English was chosen as Standard English and offers a detailed analysis of consonants and vowels in British English and their pronunciations. Next, this paper contrasts the Yuxi dialect and British English and forms this conclusion:

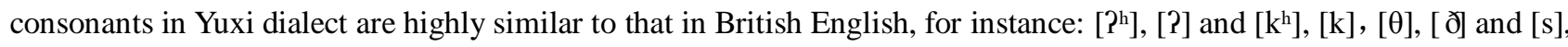
$[\mathrm{z}],[\mathrm{n}]$ and $[\mathrm{m}],[\mathrm{y}]$. As to the vowel, due to their different vocal organs, Chinese and utter vowels differ.

Based on the findings of people who studied this topic before, this paper proposes the first method to deal with the mispronunciations of English words. First, this essay introduces the characteristics of the Yuxi dialect, including vowels and consonants. Then the writer explains the reasons of Received Pronunciation as the Standard English in respect of vowels and consonants.

This essay puts emphasis on the comparison of consonants and vowels between the Yuxi dialect and Received Pronunciation. Then the differences generalized from the comparison are employed to develop the rectifications for mispronunciations in English learning, which is intended to improve English teaching quality in the Yuxi.

Because the writer only has a short learning of phonetics, the analysis that appears in this paper is limited in both depth and width. The writer sincerely hopes that future professors who study this topic should be generous in offering him advice of revision.

\section{REFERENCES}

[1] Dianfu Chou. (1985). International Phonetic Self-study Manual. Beijing: Commercial Press.

[2] Fengtong Chang. (2004). The General Received Pronunciation of British English. Chengdu: Si Chuan University Press.

[3] Fu Chang. (1991). An overview of Yuxi dialect. Yuxi: Yuxi Normal University, 4, 32-33.

[4] TaiLong Tan. (2013). A Course of General Chinese History. Beijing: Peking University.

[5] Weidong Tai. (2013). A new concise course in linguistics for students of English. Shanghai: Shanghai Foreign Language Education Press.

[6] Yamin Tang. (2015). Yunnan Yuxi (volumes: Hongta). Kunming: Intellectual Property Right Press.

[7] Yongtao Zhu. (2011). The Society and Culture of Major English-Speaking Countries. 3nd ed. Beijing: Higher Education Press.

Yuanfei Yao was born in Yuxi, China in 1991. He is a graduate at West China of Normal University. His research interests include Anglo-American literature, Linguistics and Translation. 